\title{
A Preliminary Investigation of the Polar Lipids in Recent Tropical Sediments from Aquatic Environments at Campos dos Goytacazes, Brazil
}

\author{
Débora de A. Azevedo* \\ Instituto de Química, Universidade Federal do Rio de Janeiro, Centro de Tecnologia, Bl. A, Ilha do Fundão, \\ 21949-900 Rio de Janeiro - RJ, Brazil
}

\begin{abstract}
As frações polares dos extratos de sedimentos dos rios Imbé, Urubu e Ururaí e da Lagoa de Cima foram analisados por cromatografia gasosa e por cromatografia gasosa acoplada a espectrometria de massas. Os seguintes compostos se encontravam dominantes entre os esteróis: colest-5-en-3 $\beta$-ol, 24 -metilcolest-5-en-3 $\beta$-ol, 24 -etilcolest-5-en-3 $\beta$-ol, 24-etilcolest-5,22-dien-3 $\beta$-ol e seus respectivos $5 \alpha$-isômeros. Nos sedimentos desses sistemas aquáticos, os esteróis C29 se encontravam mais abundantes, enfatizando a alta contribuição de plantas superiores para a matéria orgânica. Já no Rio Ururaí, há um predomínio do colesterol, refletindo a maior contribuição de algas/bactérias. Olean12-en-3 $\beta$-ol ( $\beta$-amirina) e friedelan-3-ona foram os triterpenóides que prevaleceram nos sedimentos dos rios Imbé e Urubu, mas não foram detectados na Lagoa de Cima. As informações retiradas das análises dos quatro sedimentos apontaram para uma contribuição mista para a matéria orgânica: plantas superiores e alga/zooplancton.
\end{abstract}

The polar fractions extracted from sediments of the Imbé, Urubu, and Ururaí rivers and from Lake de Cima were analyzed using gas chromatography and gas chromatography-mass spectrometry. In the samples, cholest-5-en-3 $\beta$-ol, 24-methylcholest-5-en-3 $\beta$-ol, 24 -ethylcholest-5-en-3 $\beta$-ol, 24 ethylcholesta-5,22-dien-3 $\beta$-ol and their $5 \alpha$-counterparts were dominant among the sterols. Sediments of theses water bodies have the $\mathrm{C}_{29}$ sterols as the most abundant, emphasizing a higher plant input. In the Ururaí River, cholest-5-en-3 $\beta$-ol predominated, reflecting a major algal contribution. Olean12-en-3 $\beta$-ol ( $\beta$-amyrin) and friedelan-3-one were prevalent among the triterpenoids in the Imbé and the Urubu sediments, but were not detected at Lake de Cima. Samples of the Imbé and Urubu rivers contained appreciable concentrations of $n$-alkanols. They ranged from $\mathrm{C}_{14}$ to $\mathrm{C}_{32}$ with a maximum at $\mathrm{C}_{16}$ and with a second maximum in $\mathrm{C}_{28}$. Results of all four sediments point to a mixed contribution of higher plants and algae/zooplankton. Alkanols found in these water bodies indicate a greater contribution of higher plant material, while in sediments from the Ururaí algae/zooplankton were the main sources of the organic matter.

Keywords: sediments, alkanols, alkanoic acids, sterols

\section{Introduction}

Organic matter $(\mathrm{OM})$ in lacustrine sediments is derived from production within the aquatic system, inputs of terrestrial material from the surroundings and bacterial production within the sediments themselves. The relative importance of these two sources will be determined by local factors such as climate, nutrient supply, hydrodynamic conditions, and the biogeochemistry of lake sediments. Thus, changes in any of these aspects may be reflected in the organic components of the sediments.

*e-mail: debora@iq.ufrj.br
A number of researchers have employed lipids as biological markers in sediments as to provide historical information on organic matter accumulation in lacustrine sediments. ${ }^{1-3}$ Autochthonous and allochthonous OM inputs are easily discernible, but the former tend to be more labile than terrestrially derived counterparts. ${ }^{4}$

Although lipids usually represent a small fraction of the total organic carbon (TOC), their diversity and specificity makes them useful compounds to study the sources, and the transformation of OM. Alkanoic acids are among the most abundant biomarkers, but are considered to be relatively nonspecific source indicators. Conversely, they are one of the few indicators of bacterial contributions and may also be used to distinguish marine from 
terrigenous and algal from zooplanktonic inputs. ${ }^{5}$ Alkanoic acids in surface sediments have been used to identify sources of the organic matter ${ }^{6,7}$ as was observed in Ria Formosa Lake, Portugal. ${ }^{8}$

Sterols are among the most specific and diverse of all biological markers and can be used to trace the contribution from different algae, higher animals, vascular plants and sewage contamination. ${ }^{9-13}$

The "biomarkers approach" has several limitations, including the wide distribution of some compounds, their different reactivity, and the multiplicity of processes (biological, chemical, physical and geochemical), which modify the original source signature.

In this study, we have analyzed the polar lipids present in the extractable organic matter of sediments, which have not yet been analyzed for biolipid content, in order to elucidate their possible sources. The tropical rivers and lake, under study, are important to the city of Campos dos Goytacazes (RJ, Brazil) because they are situated in a still relatively unpolluted and scantily inhabited region that, despite the presence of many sugar-cane plantations and other farming activities, is still free from most of the problems inherent to highly populated areas. We thus set out: $i$ ) to determine the origin of the organic matter (allochthonous vs. autochthonous) present in the sediments; $i$ ) to determine if their polar lipids have a non-biogenic source; iii) to determine if there have been contributions from biomass burning; $i v$ ) to verify if there is any impact of anthropogenic activities on this environment; $v$ ) to verify if any similarities exist between the organic matter contributed to the four sites, since they are all connected.

The organic geochemistry of the northern part of the State of Rio de Janeiro remains practically unknown. On the other hand, such cannot be said about its hydrogeochemistry, ${ }^{14}$ its hydrobiology ${ }^{15}$ and its inorganic geochemistry. ${ }^{16}$ The lack of organic geochemical information led our group to study this area. As a result, we have published data regarding the aliphatic and aromatic hydrocarbon contents of these sediments. ${ }^{17,18}$

\section{Description of the sampling site}

The city of Campos dos Goytacazes is an important city in the northern part of the State of Rio de Janeiro, in which sugar cane plantation is the main economic activity (Figure 1). Sugar cane plantations surround the Urubu, Imbé, Ururaí rivers and Lake de Cima. To facilitate manual harvesting and to increase production, the sugar cane crops are always burned before being harvested. This technique generates a great cloud of smoke, which hovers over the city and the surrounding areas for many days.
Located at latitude $21^{\circ} 45^{\prime} 15^{\prime \prime} \mathrm{S}$ and longitude $41^{\circ} 19^{\prime} 28^{\prime \prime} \mathrm{W}$, roughly 28 kilometers from Campos dos Goytacazes city, Lake de Cima has a circumference of 18 kilometers and a maximum depth of 4 meters. Farms, sugar cane plantations and natural vegetation surround it and there is little traffic around. Besides, the Imbé and Urubu rivers originate in the Imbé Mountains. We may, thus, assume that these sites have suffered little or no impact at all from anthropogenic activities. Their geographic location is also shown in Figure 1.

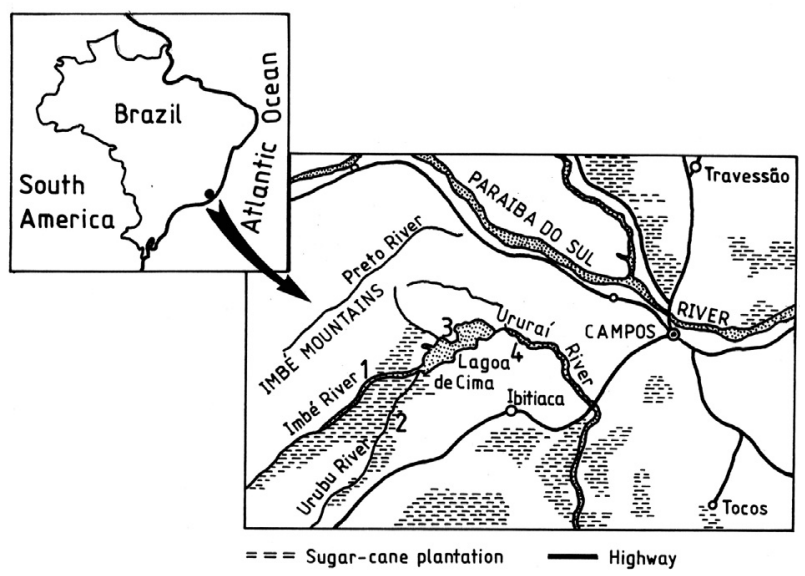

Figure 1. Map of the sampling region, showing Lake de Cima (3) and the Imbé (1), Urubu (2) and Ururaí (4) rivers. Campos dos Goytacazes is located at $21^{\circ} 45^{\prime} 15^{\prime \prime} \mathrm{S}$ and $41^{\circ} 19^{\prime} 28^{\prime \prime} \mathrm{W}$, in the State of Rio de Janeiro, Brazil.

\section{Experimental}

Surficial sediment samples were collected (05-131996) from the Urubu, Imbé and Ururaí rivers and Lake de Cima. Only one sample was collected from each site for this preliminary investigation. Sampling was carried out using a mechanical shovel. The samples were stored in a glass jar, and then frozen. Samples were lyophilized, and extracted ultrasonically for four $20 \mathrm{~min}$ periods with fresh $50 \mathrm{~mL}$ of methylene chloride: methanol (9:1- Omnisolv, Merck). The extracts were first concentrated on a rotary evaporator followed by a stream of nitrogen and separated into aliphatic and aromatic hydrocarbons, and polar compounds, by thin layer chromatography (TLC) on silica gel (developer hexane). The bands corresponding to these fractions, visualized using iodine vapor were scraped from the plates, eluted with dichloromethane, concentrated by rotary evaporation and then in a stream of nitrogen. The polar fractions were derivatized using diazomethane (to esterify alkanoic acids), followed by reaction with $\mathrm{N}, \mathrm{O}$ bis-(trimethylsilyl)-trifluoroacetamide (BSTFA, $30 \mathrm{~min}$ at $60{ }^{\circ} \mathrm{C}$ ) to convert alcohols into trimethylsilyl ethers.

The fractions were analyzed by gas chromatography (GC) and gas chromatography-mass spectrometry (CG/MS) 
by using a Hewlett Packard 5890 Gas Chromatograph and on a HP5972 Mass Selective Detector. The GC/MS and GC operating conditions were as follows: electron ionization of $70 \mathrm{eV}, 30 \mathrm{~m} \times 0.25 \mathrm{~mm}$ i.d. capillary column coated with DB-5; $\mathrm{d}_{\mathrm{f}}=0.25 \mu \mathrm{m}$ (J \& W Scientific, Folsom, CA), oven temperature program $60{ }^{\circ} \mathrm{C}$ to $300{ }^{\circ} \mathrm{C}$ at $6{ }^{\circ} \mathrm{C}$ $\mathrm{min}^{-1}$ held isothermally at $300{ }^{\circ} \mathrm{C}$ for $20 \mathrm{~min}$ : helium was used as carrier gas for GC/MS and hydrogen for GC.

Where possible, structural assignments were achieved by comparison of mass spectra with those of authentic standards, or with the help of the Wiley 138 standard library. Whenever mass spectra were unavailable, interpretation of fragmentation patterns was used together with GC relative retention times.

Quantification was performed from GC profiles using n-dodecanol (Merck - as trimethylsilyl ether) as the internal standard.

The elemental composition $(\mathrm{C}, \mathrm{H}, \mathrm{N})$ of the samples was determined using a Perkin-Elmer $2400 \mathrm{CHN}$ Analyzer and a AD-4 Autobalance.

\section{Results and Discussion}

Total ion chromatograms (TIC) of the polar fractions are shown in Figure 2. The identifications of labeled peaks are given in Table 1.

\section{Sterols, alkanols and ketones}

The sterols identified in the extractable fractions were exclusively 4-desmethylsterols. They included cholest-5en-3 $\beta$-ol (cholesterol), 24-methylcholest-5-en-3 $\beta$-ol (campesterol), 24-ethylcholest-5-en-3 $\beta$-ol (b-sitosterol), 24-ethylcholesta-5,22-dien-3 $\beta$-ol (stigmasterol) and their $5 \alpha$-counterparts. The compounds 24-ethylcholest-5-enol $\left(\mathrm{C}_{29} \Delta^{5}\right)$, 24-ethyl-5 $\alpha(\mathrm{H})$-cholestanol $\left(\mathrm{C}_{29}\right)$ and 24 ethylcholesta-5,22-dienol $\left(\mathrm{C}_{29} \Delta^{5,22}\right)$ are the most abundant in the extracted material, thus emphasizing a strong higher plant input.

As seen in Figure 3, phytosterol concentration in the Imbé, Urubu and Lake de Cima sediments, increased in the order $\mathrm{C}_{29}>\mathrm{C}_{28}>\mathrm{C}_{27}$. On the other hand, the mass fragmentograms $m / z 215$ and 129 (characteristic ions for stanols and sterols, respectively) show, in Figure 4, that cholesterol is dominant in Ururaí sediments with minor contributions of other sterols

In the sediment samples, stenols were almost as abundant as the corresponding stanols, indicating that the early diagenetic transformations of these compounds had already occurred.

$\mathrm{C}_{27}$ and $\mathrm{C}_{28}$ sterols reflect an algal contribution to the
OM. ${ }^{19}$ In contrast, although also present in some algae, ${ }^{20-22}$ the $\mathrm{C}_{29}$ compounds are ubiquitous in vascular plants, often being the dominant sterols. ${ }^{23-24}$ The relative importance of these two sources in the formation of OM will depend on the type of environment surrounding the site, on the proximity to sources of land-derived organic matter, and on the abundance and type of phytoplankton present. ${ }^{11}$ The sampled sites in the present study were situated close to land and places like or such that, so the origin of 14ethylcholest-5-en- $3 \beta$-ol is pointed as terrigenous.

The lipid material is composed of plant wax, and of components deriving from microbial detritus and algae. This interpretation is also supported by the enhanced

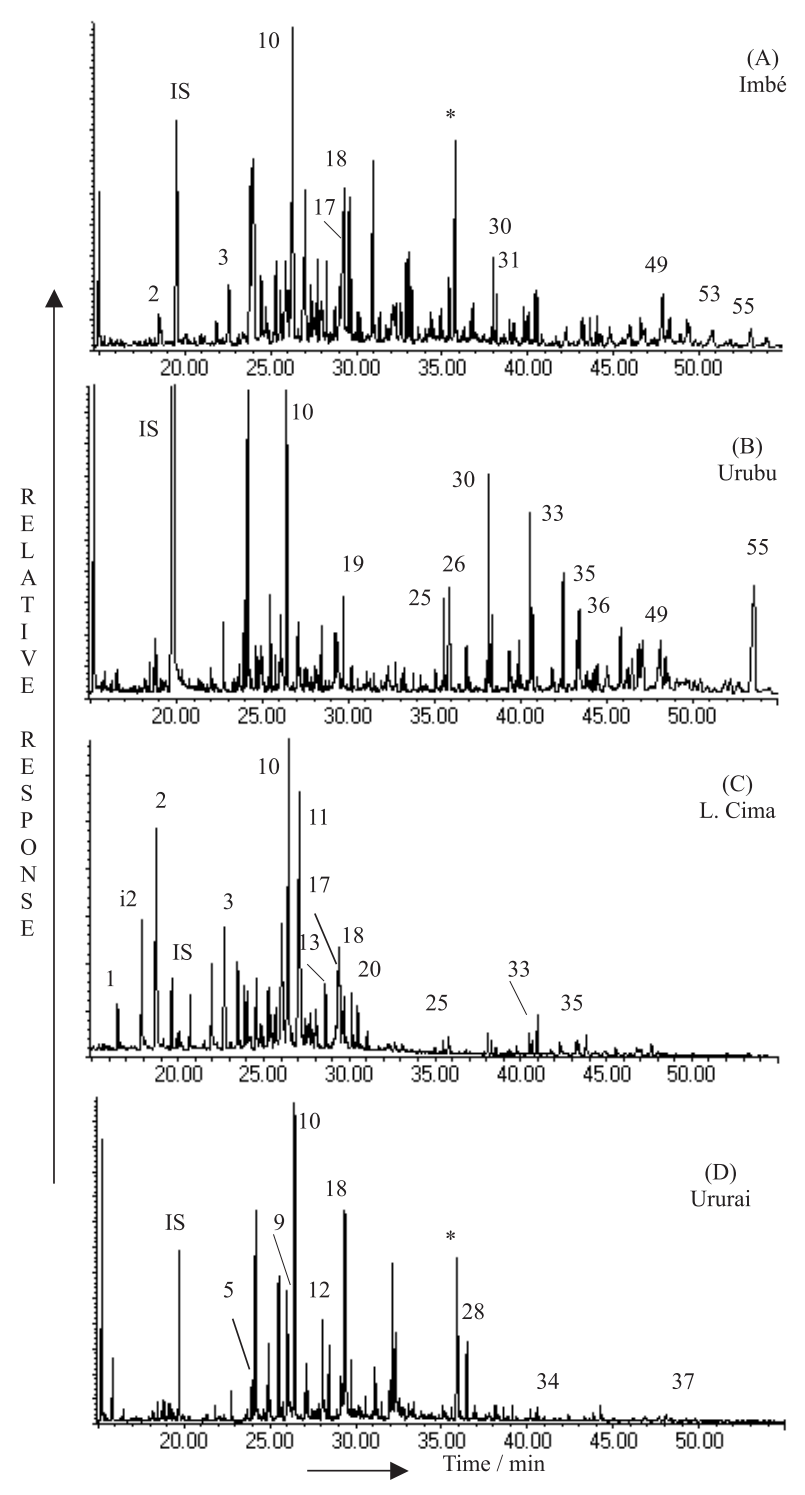

Figure 2. Total ion chromatogram of polar compounds in the: (A) The Imbé; (B) The Urubu;(C) Lake de Cima; (D) The Ururaí. (IS= internal standard; numbers are biomarkers, cf. Table 1). * Phthalate contaminants. 
Table 1. Compounds identified and quantified $\left(\mathrm{ng}^{-1}\right)$ in the samples

\begin{tabular}{|c|c|c|c|c|c|c|}
\hline № & Compounds & $\begin{array}{l}\text { Diagnostic } \\
\text { ions }(m / z)\end{array}$ & $\begin{array}{l}\text { Lake de } \\
\text { Cima }\end{array}$ & $\begin{array}{l}\text { Imbé } \\
\text { River }\end{array}$ & $\begin{array}{l}\text { Urubu } \\
\text { River }\end{array}$ & $\begin{array}{l}\text { Ururaí } \\
\text { River }\end{array}$ \\
\hline 1 & decanoic acid & $74 / 186$ & + & $\mathrm{nd}$ & $\mathrm{nd}$ & $\mathrm{nd}$ \\
\hline 2 & Dodecanoic acid & $74 / 214$ & $4.62 / 10.53^{\mathrm{a}}$ & $\mathrm{nd}$ & $\mathrm{nd}$ & $\mathrm{nd}$ \\
\hline IS & dodecanol (internal standard) & $75 / 243$ & nd & $\mathrm{nd}$ & $\mathrm{nd}$ & $\mathrm{nd}$ \\
\hline 3 & tetradecanoic acid & $74 / 242$ & $3.35 / 5.74^{\mathrm{a}}$ & 0.0038 & 6.87 & 77.83 \\
\hline 4 & tetradecanol & $75 / 271$ & $\mathrm{nd}$ & + & $\mathrm{nd}$ & $\mathrm{nd}$ \\
\hline 5 & pentadecanoic acid & $74 / 256$ & $\mathrm{nd}$ & + & $\mathrm{nd}$ & + \\
\hline 6 & 2-pentadecanone, 6,10,14-trimethyl- & $58 / 250 / 268$ & $\mathrm{nd}$ & + & $\mathrm{nd}$ & $\mathrm{nd}$ \\
\hline 7 & pentadecanol & $75 / 285$ & $\mathrm{nd}$ & + & $\mathrm{nd}$ & $\mathrm{nd}$ \\
\hline 8 & tetradecanoic acid, trimethylsilyl ether & $117 / 285 / 300$ & $\mathrm{nd}$ & + & $\mathrm{nd}$ & $\mathrm{nd}$ \\
\hline 9 & hexadecenoic acid & $74 / 96 / 268$ & $\mathrm{nd}$ & + & $6.68 / 1.55^{\mathrm{a}}$ & $298.55 / 157.59^{\mathrm{a}}$ \\
\hline 10 & hexadecanoic acid & $74 / 270$ & 25.11 & 0.138 & 23.27 & 810.78 \\
\hline 11 & hexadecanol & $75 / 299$ & 29.74 & 0.022 & 6.84 & 67.80 \\
\hline 12 & hexadecanoic acid,1-methyl, ethyl ester & 298 & $\mathrm{nd}$ & + & $\mathrm{nd}$ & $\mathrm{nd}$ \\
\hline 13 & hexadecanoic acid, trimethylsilyl ether & $117 / 313 / 328$ & 4.39 & 0.026 & $\mathrm{nd}$ & $\mathrm{nd}$ \\
\hline 14 & hexadecanoic acid, 14-methyl- & $74 / 284$ & $\mathrm{nd}$ & nd & $\mathrm{nd}$ & $\mathrm{nd}$ \\
\hline 15 & heptadecanoic acid & $74 / 284$ & + & + & $\mathrm{nd}$ & 92.49 \\
\hline 16 & heptadecanol & $75 / 313$ & $\mathrm{nd}$ & + & $\mathrm{nd}$ & $\mathrm{nd}$ \\
\hline 17 & octadecadienoic acid & 294 & 8.59 & 0.0199 & 2.49 & 40.05 \\
\hline 18 & octadecenoic acid & 296 & 6.99 & 0.0608 & 3.55 & 281.69 \\
\hline 19 & octadecanoic acid & $74 / 298$ & 4.65 & 0.043 & 3.75 & 64.65 \\
\hline 20 & octadecanol & $75 / 327$ & 4.10 & 0.010 & 0.83 & 13.58 \\
\hline 21 & octadecanoic acid, trimethylsilyl ether & $117 / 341 / 356$ & $\mathrm{nd}$ & + & $\mathrm{nd}$ & $\mathrm{nd}$ \\
\hline 22 & eicosanoic acid & $74 / 326$ & 1.35 & 0.016 & 1.43 & 14.34 \\
\hline 23 & eicosanol & $75 / 355$ & 0.98 & + & 0.95 & $\mathrm{nd}$ \\
\hline 24 & heneicosanoic acid & $74 / 340$ & $\mathrm{nd}$ & + & nd & $\mathrm{nd}$ \\
\hline 25 & docosanoic acid & $74 / 354$ & 1.69 & 0.0142 & 2.03 & 7.58 \\
\hline 26 & docosanol & $75 / 383$ & 2.16 & 0.0082 & 3.47 & $\operatorname{tr}$ \\
\hline 27 & tricosanoic acid & $74 / 368$ & nd & + & 0.83 & $\mathrm{nd}$ \\
\hline 28 & hexadecanoic acid, 2,3-bis[(trimethylsilyl)oxy]prop & $73 / 371 / 459$ & $\mathrm{nd}$ & + & $\mathrm{nd}$ & 45.31 \\
\hline 29 & eicosanoic acid, trimethylsilyl ether & $117 / 369 / 384$ & $\mathrm{nd}$ & 0.0147 & $\mathrm{nd}$ & nd \\
\hline 30 & tetracosanoic acid & $74 / 382$ & 5.11 & 0.031 & 4.16 & 10.07 \\
\hline 31 & tetracosanol & $75 / 411$ & 3.97 & 0.0089 & 1.23 & + \\
\hline 32 & pentacosanoic acid & $74 / 396$ & $\mathrm{nd}$ & + & nd & nd \\
\hline 33 & hexacosanoic acid & $74 / 410$ & 6.49 & 0.0251 & 3.48 & 26.94 \\
\hline 34 & hexacosanol & $75 / 439$ & 5.73 & 0.018 & 1.21 & 10.03 \\
\hline 35 & octacosanoic acid & $74 / 438$ & 3.52 & 0.0276 & 1.78 & + \\
\hline 36 & octacosanol & $75 / 467$ & 5.96 & 0.0226 & 2.23 & + \\
\hline 37 & cholest-5-en-3 $\beta$-ol (cholesterol) & $129 / 458$ & 2.63 & 0.0381 & 0.94 & 20.41 \\
\hline 38 & $5 \alpha$-cholestan- $3 \beta$-ol (cholestanol) & $215 / 460$ & 2.78 & 0.0193 & 0.94 & $\operatorname{tr}$ \\
\hline 39 & 24 -methylcholesta-5,22-dien- $3 \beta$-ol & $129 / 470$ & $\mathrm{nd}$ & 0.0608 & $\mathrm{nd}$ & nd \\
\hline 40 & 24 -methyl- $5 \alpha$-cholest- 22 -en- $3 \beta$-ol & $257 / 472$ & $\mathrm{nd}$ & $\operatorname{tr}$ & $\mathrm{nd}$ & $\mathrm{nd}$ \\
\hline 41 & 24-methylcholest-5-en-3 $\beta$-ol (campesterol) & $129 / 472$ & 4.06 & 0.0425 & 0.75 & $\operatorname{tr}$ \\
\hline 42 & 24-methy- $5 \alpha$-cholestan- $3 \beta$-ol (campestanol) & $215 / 474$ & 1.98 & 0.0120 & 1.63 & $\mathrm{nd}$ \\
\hline 43 & 24-ethylcholesta-5,22-dien-3 $\beta$-ol (stigmasterol) & $129 / 484$ & 6.53 & 0.0407 & 2.32 & + \\
\hline 44 & triacontanoic acid & $74 / 466$ & 4.42 & 0.0188 & 0.92 & $\mathrm{nd}$ \\
\hline 45 & triacontanol & $75 / 495$ & 4.68 & 0.0189 & 0.92 & $\mathrm{nd}$ \\
\hline 46 & 24 -ethyl- $5 \alpha$-cholesta-22-en-3 $\beta$-ol (stigmastanol) & $257 / 486$ & $\operatorname{tr}$ & $\operatorname{tr}$ & $\mathrm{nd}$ & $\mathrm{nd}$ \\
\hline 47 & triterpanol 01 & $218 / 498$ & $\mathrm{nd}$ & $\mathrm{nd}$ & + & $\mathrm{nd}$ \\
\hline 48 & olean-12-en-3-one & $218 / 424$ & $\mathrm{nd}$ & $\mathrm{nd}$ & + & nd \\
\hline 49 & 24 -ethyl-cholesta-5-en- $3 \beta$-ol ( $\beta$-sitosterol) & $129 / 486$ & 5.61 & 0.0966 & 1.52 & $\operatorname{tr}$ \\
\hline 50 & 24 -ethyl- $5 \alpha$-cholestan- $3 \beta$-ol ( $\beta$-sitostanol $)$ & $215 / 488$ & 4.18 & 0.0712 & 2.55 & $\operatorname{tr}$ \\
\hline 51 & olean-12-en-3 $\beta$-ol ( $\beta$-amyrin $)$ & $218 / 498$ & $\mathrm{nd}$ & 0.0622 & 1.50 & $\mathrm{nd}$ \\
\hline 52 & triterpenol 02 & $189 / 498$ & $\mathrm{nd}$ & 0.0551 & nd & nd \\
\hline 53 & triterpenone 01 & $191 / 426$ & $\mathrm{nd}$ & 0.0613 & $\mathrm{nd}$ & $\mathrm{nd}$ \\
\hline 54 & triterpenone 02 & $191 / 426$ & $\mathrm{nd}$ & 0.0659 & $\mathrm{nd}$ & $\mathrm{nd}$ \\
\hline 55 & friedelan-3-one & $205 / 273 / 426$ & $\mathrm{nd}$ & 0.0757 & 14.35 & $\mathrm{nd}$ \\
\hline
\end{tabular}

$\overline{\mathrm{nd}}=$ not detected; $+=$ detected but not quantified; $\mathrm{tr}=$ identified in trace quantities; ${ }^{\text {a }}$ two distinct isomers given as the methyl esters for the carboxylic acids and trimethylsilyl ether for alcohols. 

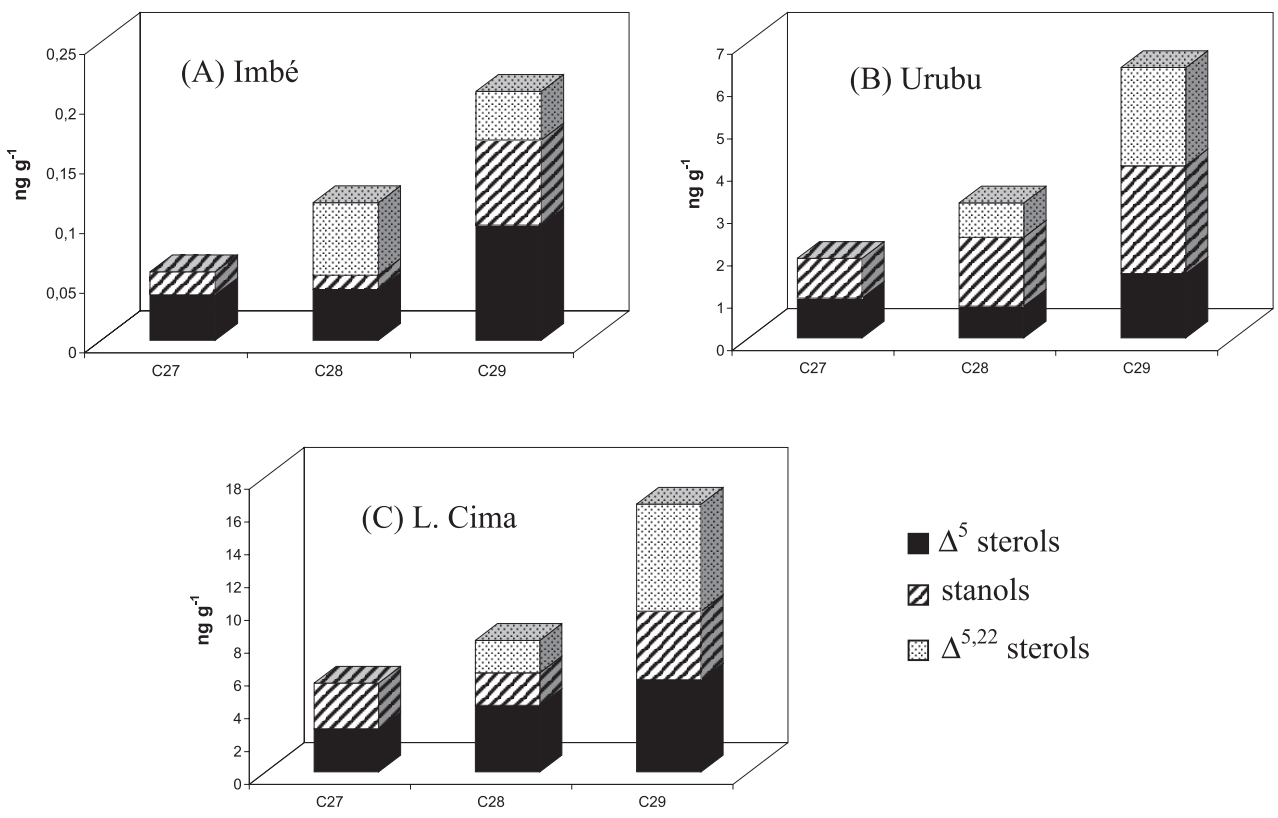

$$
\begin{aligned}
& \text { 口 } \Delta^{5} \text { sterols } \\
& \text { stanols } \\
& \Delta^{5,22} \text { sterols }
\end{aligned}
$$

Figure 3. Distribution histograms for phytosterols [concentration is plotted vs. carbon number]: (A) The Imbé; (B) The Urubu; (C) Lake de Cima.

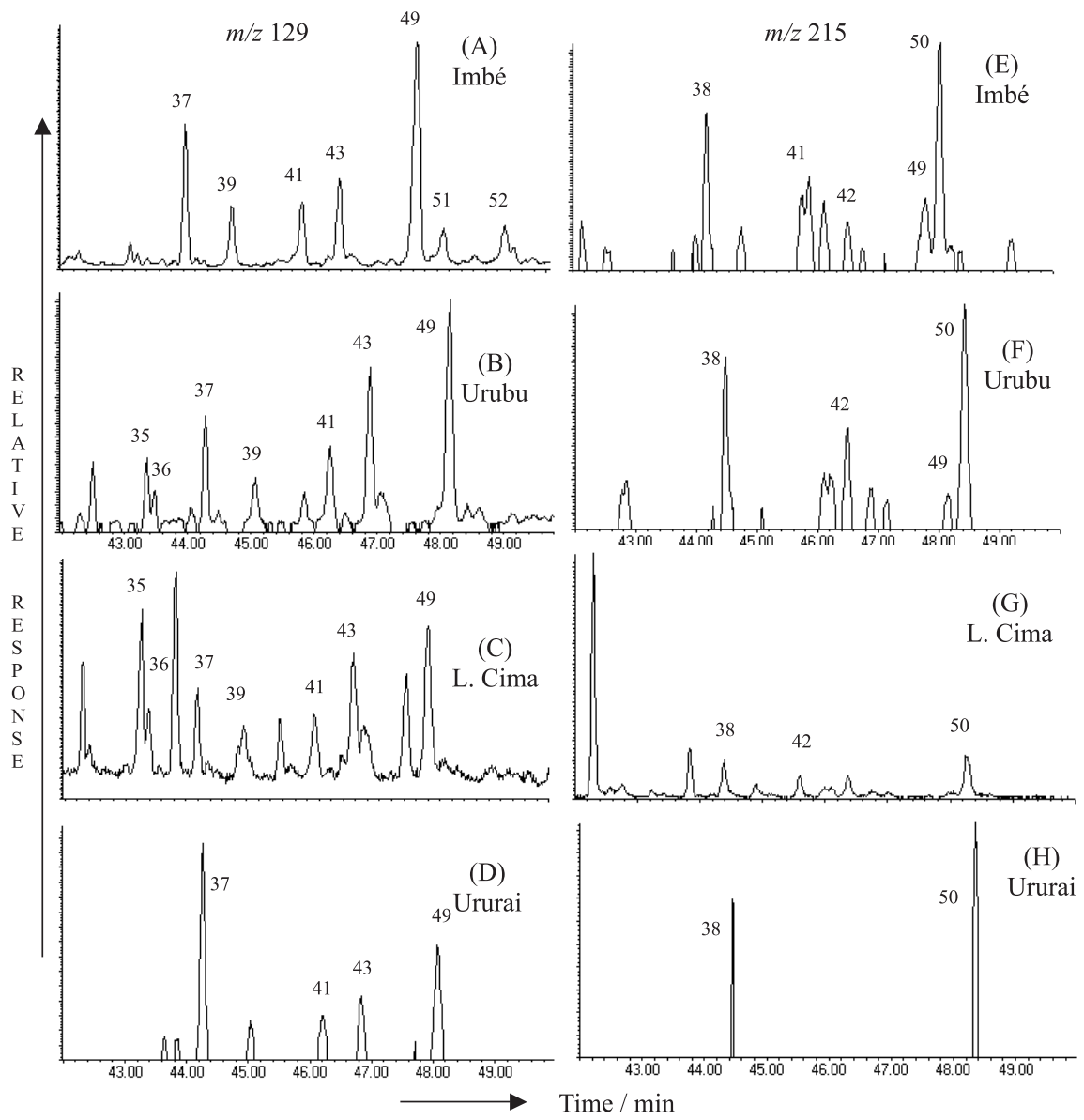

Figure 4. Mass fragmentograms $(m / z, 129)$ of the characteristic ion for sterols: (A) The Imbé; (B) The Urubu; (C) Lake de Cima; (D); The Ururaí and mass fragmentograms $(\mathrm{m} / \mathrm{z}, 215)$ of the characteristic ion for stanols: The Imbé; (F) The Urubu; (G) Lake de Cima; (H) The Ururaí (as trimethylsilyl ethers) for the polar compounds fractions. (numbers 14-32 refer to carbon chain length of homologous series). 
concentration of cholesterol, abundant in many freshwater algae and zooplankton. Hence, its occurrence in the Ururaí sediment probably arose mainly from an autochthonous planktonic input. The presence of substantial concentrations of 24-ethylcholesta-5,22-dienol $\left(\mathrm{C}_{29} \Delta^{5,22}\right)$ and 24-ethylcholest-5-enol $\left(\mathrm{C}_{29} \Delta^{5}\right)$, and of less amount of their 24-methyl counterparts in the Urubu, Imbé, and Lake de Cima sediments indicate the abundance of a vascular plant input. Note that these compounds have also been detected in high concentrations in soils adjacent to other tropical riverine systems. ${ }^{25}$

Hydrogenation of the $\Delta^{5}$ double bond yields stanols with $5 \alpha(\mathrm{H})$ and $5 \beta(\mathrm{H})$ configurations. Hydrogenation in oxygenated sediments favors the $5 \alpha$ form, whereas the $5 \beta$ form is favored in strongly anoxic sediments. ${ }^{26}$ In the sediments under study, only $5 \alpha(\mathrm{H})$-stanols (Table 1$)$ were detected, indicating an oxygenated sedimentary environment.

Olean-12-en-3 $\beta$-ol ( $\beta$-amyrin) and friedelan-3-one were prevalent among the triterpenoids in the Imbé and Urubu samples. $\alpha$-Amyrin was not detected in these samples although it is usually found in conjunction with $\beta$-amyrin in many recent sediments. Other triterpenoids are also present, but they could not be identified (see Table 1) in this and on the other two sediments. It is important to note that pentacyclic 3-oxytriterpenoids were very abundant in the soil samples from the Orinoco Basin studied by Jaffé and coworkers (1996). ${ }^{27}$ It has been suggested that the bulk of the dissolved and particulate organic carbon in tropical rivers derives from highly degraded soil materials, and that, the lipid fraction of such organic phases show a relatively high contribution of autochthonous organic matter. ${ }^{25,27}$ The same patterns seem to occur in the tropical sediments now under study.

$n$-Alkanols are present in all four samples. They range from $\mathrm{C}_{14}$ to $\mathrm{C}_{32}$ with a maximum at $\mathrm{C}_{16}$ and a strong even carbon number predominance (see Table 2 and Figure 5). A better visualization of the alkanols was obtained from fragmentograms of $n$-alkanol trimethylsilyl ethers using the $[\mathrm{M}-15]^{+}$ion. The Imbé and Urubu samples display a bimodal distribution with maxima at $\mathrm{C}_{16}$ and $\mathrm{C}_{28}$. This indicates both algal and /or bacterial $\left(\mathrm{C}_{16}-\mathrm{C}_{18}\right)$ and higher plant $\left(>\mathrm{C}_{22}\right)$ contributions, as illustrated in Figure 6(A-C) and Table 2. Thus, in Figure 6C indicates that Lake de Cima receives a large input of $n$-alkanols from algae/zooplankton but minor contributions of higher $\left(\mathrm{C}_{24}-\mathrm{C}_{30}\right) n$-alkanols. A very similar trend was observed for the Ururaí samples.

The distribution, and the relative concentration, of $n$ alkanols in the Imbé and Urubu samples seem to indicate a predominant higher plant, allochthonous source. Contrastingly, the presence of lower molecular weight
Table 2. Sediment samples from the rivers Imbé, Urubu, Ururaí and Lake de Cima analytical results

\begin{tabular}{lllll}
\hline & de Cima & Imbé & Urubu & Ururaí \\
\hline$\%$ Bitumen & 0.402 & 0.009 & 0.113 & 0.042 \\
$\% \mathrm{C}$ & 3.00 & 0.15 & 2.39 & 0.25 \\
$\% \mathrm{H}$ & 0.77 & 0.04 & 0.36 & 0.12 \\
$\% \mathrm{~N}$ & 0.30 & 0.01 & 0.14 & 0.08 \\
$\mathrm{C} / \mathrm{H}$ & 3.9 & 3.8 & 6.6 & 2.1 \\
$\mathrm{C} / \mathrm{N}$ & 10.0 & 15 & 17.1 & 3.1 \\
$\mathrm{Cmax} n$-alkanols $^{\mathrm{b}}$ & $\underline{16 / 28}$ & $16 / \underline{28}$ & $16 / \underline{28}$ & $\underline{16}$ \\
$\mathrm{CPI} n$-alkanols $^{\mathrm{a}}$ & 4.9 & 6.5 & 4.7 & 3.9 \\
$\mathrm{Cmax}$ acidss & $\underline{16 / 26}$ & $\underline{16 / 24}$ & $\underline{16 / 24}$ & $\underline{16 / 26}$ \\
CPI acids $^{\mathrm{a}}$ & 4.6 & 4.0 & 5.9 & 5.8 \\
\hline
\end{tabular}

${ }^{\mathrm{a}} \mathrm{CPI}=$ Carbon Preference Index. ${ }^{\mathrm{b}}$ Carbon chain maxima in homologous series (dominant homolog is underlined)

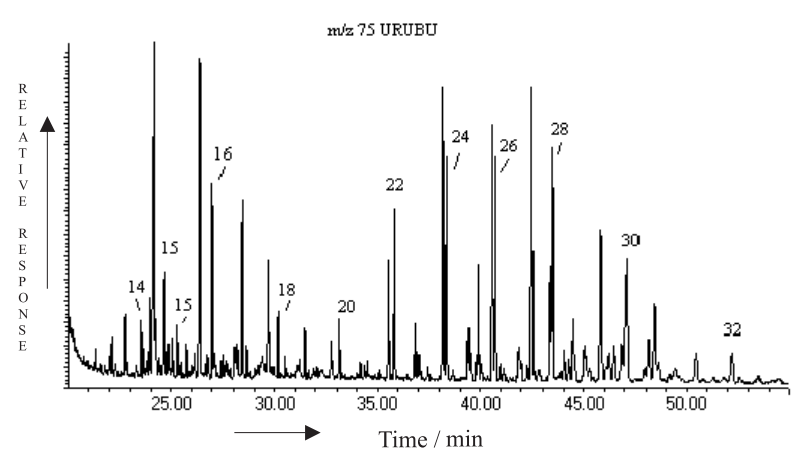

Figure 5. Mass fragmentogram $(m / z$ 75) characteristic ion for $n$ alkanols (as trimethylsilyl ethers) for the polar compounds fractions of the Urubu (numbers 14-32 refer to carbon chain length of homologous series).

compounds in appreciable concentrations in Lake de Cima and Ururaí sediments suggests the existence of an additional algal/bacterial source.

\section{Alkanoic acid}

The distribution of $n$-alkanoic acids in our four samples is given in Figure 6(D-G), which shows that hexadecanoic acid $\left(\mathrm{nC}_{16}\right.$; Figure 2 ) predominates. In sediments from the Imbé, Urubu and Lake de Cima, alkanoic acids range from $\mathrm{C}_{12}$ to $\mathrm{C}_{30}$, with a bimodal distribution and a second maximum at $\mathrm{C}_{24} / \mathrm{C}_{26}$. Although long chain alkanoic acids $\left(\mathrm{C}_{22}-\mathrm{C}_{30}\right)$ derive primarily from higher plants, ${ }^{24}$ short-chain acids are ubiquitous, being found in algae, ${ }^{20,28}$ higher plants, ${ }^{24,29}$ bacteria and fungi. ${ }^{4}$

Some unsaturated alkanoic acids, e.g., hexadecenoic acid $\left(\mathrm{C}_{16: 1}\right)$, octadecenoic acid $\left(\mathrm{C}_{18: 1}\right)$ and octadecadienoic acid $\left(\mathrm{C}_{18: 2}\right)$ were also observed in the samples. The presence of unsaturated alkanoic acids, mainly the $\mathrm{C}_{18: 1}$ with some $\mathrm{C}_{16: 1}$ and $\mathrm{C}_{20: 1}$, are indicators of recent biogenesis, and are 

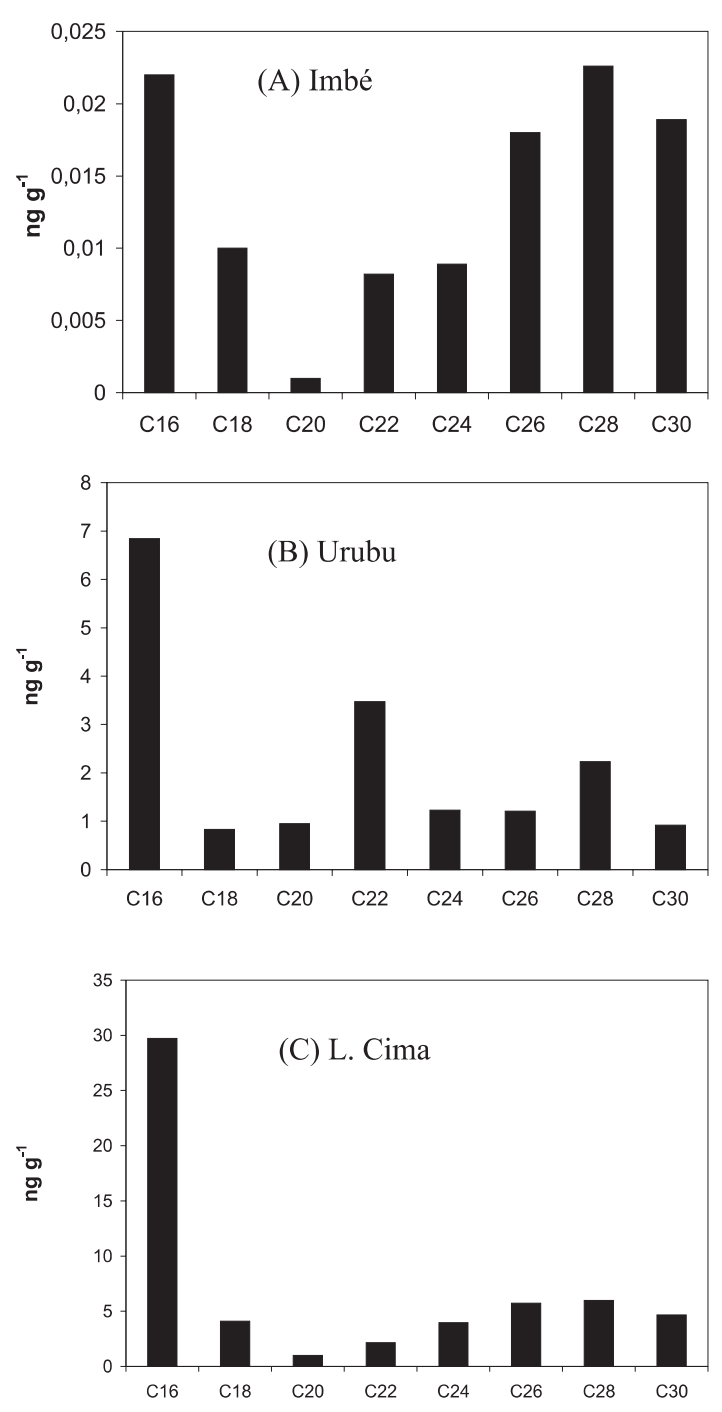
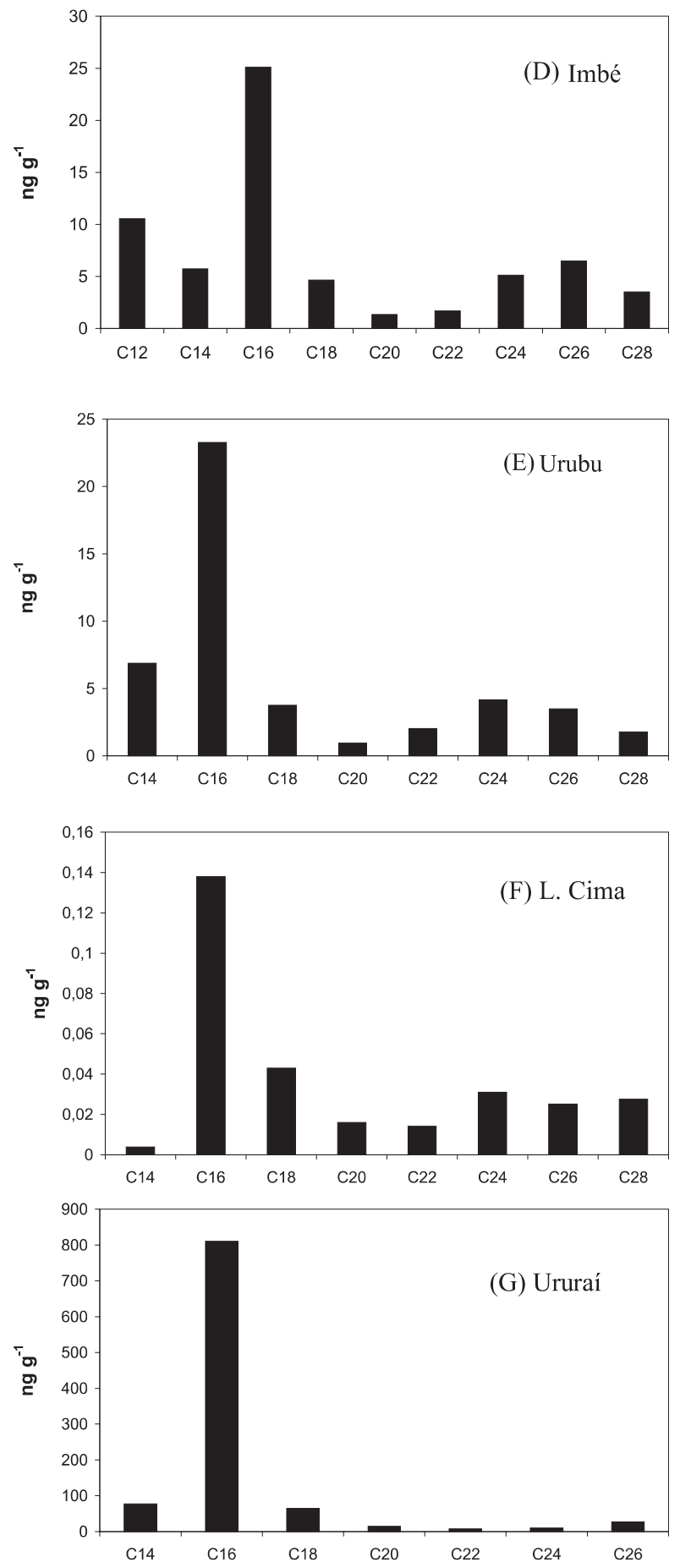

Figure 6. Distribution diagrams [concentrations are plotted vs. carbon number] for: $n$-alkanols; (A) The Imbé; (B) The Urubu; (C) Lake de Cima and $n$-alkanoic acids; (D) The Imbé; (E) The Urubu; (F) Lake de Cima; (G) The Ururaí.

present in all recent sediment samples..$^{30} \mathrm{C}_{18: 1}$ was also reported in aerosol vegetation wax and river sediments in the Amazonian region. ${ }^{31}$ Iso- and anteiso-pentadecanoic, heptadecanoic, iso-tetradecanoic and hexadecanoic acids were also present in the four samples. The presence of isoand anteiso-acids, especially in surficial sediments, is characteristic of a bacterial input. ${ }^{32}$ Anteiso- and isoalkanoic acids $\left(\mathrm{C}_{13}-\mathrm{C}_{17}\right)$ are commonly found in microbial lipids, lending further support to a possible recent biological origin. ${ }^{25,33}$

Alkenoic acids $\left(n \mathrm{C}_{14: 0}, n \mathrm{C}_{16: 0}, n \mathrm{C}_{16: 1}\right)$ are abundant in phytoplankton, while $n \mathrm{C}_{16: 0}, n \mathrm{C}_{18: 1}$ and $n \mathrm{C}_{18: 0}$ often 
predominate in zooplankton. Diatoms are rich in $n \mathrm{C}_{14: 0}$, $n \mathrm{C}_{16: 0}$ and $n \mathrm{C}_{16: 1}$ alkenoic acids, and low in $\mathrm{C}_{18}$ homologues. In contrast, $n \mathrm{C}_{18: 1}, n \mathrm{C}_{18: 2}, n \mathrm{C}_{18: 3}$ and $n \mathrm{C}_{18: 4}$ predominate in flagellates and freshwater algae. However, higher plants also contain the more specific saturated $\mathrm{C}_{22}-\mathrm{C}_{32}$ series. $\mathrm{C}_{14}-\mathrm{C}_{16}$ alkanoic acids are found in higher plants, green algae or bacteria.

Because alkenoic acids are known to be more susceptible to degradation than their saturated counterparts, their abundant presence in the sediments being analyzed, indicate the relative freshness of the collected material.

The distribution of alkanoic acids in these tropical sediments suggests a dominant phytoplankton, zooplankton and microbial input (short-chain and unsaturated acids; $<\mathrm{C}_{20}$ ) with a minor contribution from higher plants (long-chain; $>\mathrm{C}_{21}$ ). Branched alkanoic acids, such as the iso- and anteiso- $\mathrm{C}_{15}$ compounds reflect bacterial contributions to the OM.

\section{Organic matter}

Sedimentary organic $\mathrm{C} / \mathrm{N}$ ratios are useful in distinguishing between an algal and vascular land-plant origin of organic matter. The presence or absence of cellulose in the plants sourcing organic matter influences the $\mathrm{C} / \mathrm{N}$ ratios in sediments. Nonvascular aquatic plants have low $\mathrm{C} /$ $\mathrm{N}$ ratios, typically between 4 and 10, whereas vascular land plants, which contain cellulose, have $\mathrm{C} / \mathrm{N}$ ratios of 20 or greater. Lakes for which the contribution of organic matter from vascular land plants is small, relative to that produced in the water-column, exemplified by Walker Lake $(\mathrm{C} / \mathrm{N}=8)$ and Lake Michigan $(\mathrm{C} / \mathrm{N}=9)$, show lower $\mathrm{C} / \mathrm{N}$ ratios in their sediments than do lakes receiving substantial amounts of vascular plant debris, such as Lake Mangrove $(\mathrm{C} / \mathrm{N}=13)$ and Lake Bosumtwi $(\mathrm{C} / \mathrm{N}=14)$. Ratios of 13-14 for the surface sediments of lakes suggest a mixture of non-vascular and vascular contributions, a situation expected for most lakes. ${ }^{26,34,35}$

The organic matters in our samples appear to originate from both autochthonous and allochthonous sources. For example, the $\mathrm{C} / \mathrm{N}$ ratios for sediments from Lake de Cima, and the Imbé and Urubu rivers (10, 15 and 17, respectively; see Table 2) are intermediate to those characteristic of landderived OM (20-100) and of aquatic algae and bacteria derived OM (5-8). ${ }^{2,36}$ For the Ururaí sample, the value (3; see Table 2) is closer to aquatic algae, bacteria and nonvascular aquatic plants. This low value might be due to plankton and/or microbial action on organic matter: microbial degradation generally decreases the $\mathrm{C} / \mathrm{N}$ ratio (microbial immobilization of nitrogen and mineralization of carbon). Because the $\mathrm{C}$ content is low, the presence of ammonia in clay minerals could also cause the lower $\mathrm{C} / \mathrm{N}$ ratio.

\section{General observations}

Hydrocarbon fractions from these sediments had already been analyzed by our group. ${ }^{17,18}$ In the sample from Lake de Cima, fluoranthene, pyrene and chrysene had been detected, and quantified, but solely at trace levels. No hopanes, steranes, nor an unresolved complex mixture (UCM) was observed in any samples. Moreover, most of the aromatic hydrocarbons were of biogenic origin; for example tetramethyloctahydropicene, 3,3,7-trimethyl1,2,3,4-tetramethylhydrochrysene and cadalene. The same behavior has been verified now in this study of the polar organic compounds.

In addition to the local sources of organic matter, winds commonly transport material such as pollen and particulate matter from sources outside the local watershed. The eolian component is typically a small fraction of the total organic mixture, yet it can contain distinctive components potentially useful to paleolimnetic and paleoclimatic studies. ${ }^{26}$ In contrast to what was observed in surface sediments from the Amazon shelf, ${ }^{37}$ the specific biomass burning biomarker, levoglucosan, though detected in the atmospheric particulate matter over Campos dos Goytacazes, ${ }^{38}$ was not detected in the four samples discussed in this article. This fact precludes the contribution of significant inputs from airborne sources to these sediments, but a smaller anthropogenic contribution should not be excluded, as they are also common biomarkes transported by aerosols. ${ }^{30,33,39,40}$

In other words, although a great cloud of smoke, deriving from the burning of sugar cane hovers continually over the studied area, no parameter corroborating a significant input from anthropogenic origins could be identified or detected in theses samples.

Previous studies have suggested that the OM present in most tropical rivers derives from allochthonous OM. However, substantial contributions of autochthonous algal and bacterially-derived compounds to the total lipids is also evident in tropical river samples. ${ }^{25}$ In the present study, the same pattern observed by Jaffé and coworkers for the tropical rivers of the Orinoco Basin (Venezuela) was also observed. The rivers Imbé, Urubu and Lake de Cima received contributions from both allochthonous and autochthonous sources, but their samples show a marked predominance of an allochthonous input. Contrastingly, the Ururaí sediment displayed a significant contribution from autochthonous sources (greater abundance of $\mathrm{C}_{27}$ sterol and a large input of $\mathrm{C}_{16} n$-alkanoic acid). 


\section{Conclusions}

This survey indicated that sterols, $n$-alkanols, alkanoic acids and some ketones were present in our sediment samples. Plant wax components were characterized mainly by the distribution homologous of $n$-alkanols (even, $\mathrm{C}_{24}{ }^{-}$ $\mathrm{C}_{32}$ ), alkanoic acids (even, $\mathrm{C}_{20}-\mathrm{C}_{32}$ ) and $\mathrm{C}_{29}$ phytosterols. Triterpenols, and some derivatives deriving from plant wax, were also found in the Imbé and Urubu samples. The presence of these compounds confirms that they originate from higher plant waxes. The microbial lipid contribution is made evident by the presence of alkanoic acids and alcohols $\left(<\mathrm{C}_{20}\right)$, and of cholesterol.
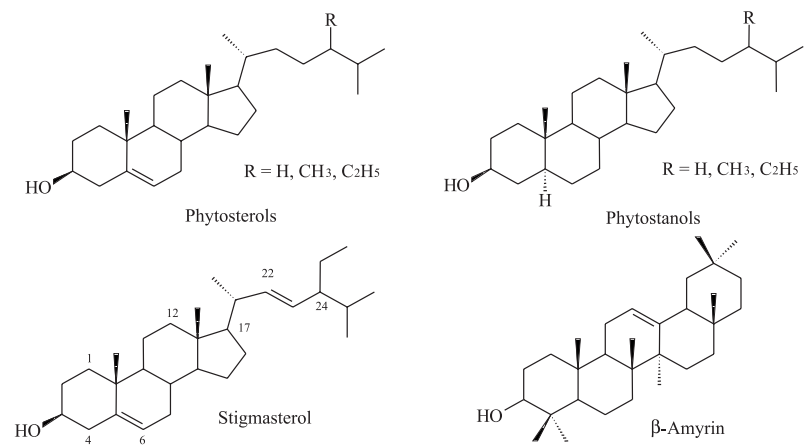

Examination of the sterols, $n$-alkanols and $n$-alkanoic acids present and of the $\mathrm{C} / \mathrm{N}$ ratio, indicates that all sediments have had a mixed contribution from higher plants and algae/zooplankton. The samples from the Imbé, Urubu Rivers and from Lake de Cima showed a major input from higher plants, but also showed a contribution from algae/zooplankton. The Ururaí sediment showed a reversed trend. This trend was also observed in the hydrocarbons distribution. ${ }^{17,18}$

As the polar organic matter originates mainly from higher plants in the Imbé, Urubu and Lake Cima sediments, a certain relationship can be established. Conversely, it seems that the relationship between them and the Ururaí is slight. It should be noted that even if these sites are physically connected, the organic matter present in the Ururaí sediment has an origin distinct that present in the sediments of the others.

In spite of the clouds of smoke, caused by burning crops, which hovers continually over the area, Levoglucosan, a biomass burning biomarker, was not detected in the samples analyzed.

No major impact from anthropogenic activity was observed at any of these sites: the most abundant contribution to their polar organic matter was of biogenic origin.

\section{Acknowledgments}

FAPERJ, FUFB and CNPq are acknowledged for financial support to this project. Dr. F. R. Aquino Neto (IQUFRJ) and Dr. J. O. Grimalt (CSIC-Spain) are acknowledged for comments and suggestions and Dr. Carlos Rezende (UENF) is acknowledged for samples collection.

\section{References}

1. Cranwell, P.A.; Org. Geochem. 1981, 3, 79.

2. Meyers, P.A.; Kawka, O.E.; Whitehead, P.R.; Org. Geochem. 1984, 6, 727.

3. Wünsche, L.; Mendoza, Y.A.; Gülaçar, F.O.; Org. Geochem. 1988, 13, 1131.

4. Prartono, T.; Wolff, G.A.; Org. Geochem. 1998, 28, 729.

5. Colombo, J.C.; Silverberg, N.; Gearing, J.N.; Org. Geochem. 1996, 25, 211.

6. Grimalt, J.O.; Albaiges, J.; Mar. Geol. 1990, 95, 207.

7. Nilchols, P.D.; Klumpp, D.W.; Johns, R.B.; Phytochemistry 1982, 21, 1613.

8. Mudge, S.M.; East, J.A.; Bebianno, M.J.; Barreira, L.A.; Org. Geochem. 1998, 29, 963.

9. Hatcher, P.G.; McGillivary, P.A.; Environ. Sci. Technol. 1979, $13,1225$.

10. Huang, W-Y.; Meinschein, W.G.; Geochim. Cosmochim. Acta 1979, 43, 739.

11. Volkman, J.K.; Org. Geochem. 1986, 9, 83.

12. Grimalt, J.O.; Fernández, P.; Bayona, J.M.; Albaiges, J.; Environ. Sci. Technol. 1990, 24, 357.

13. Fernandes, M.B.; Sicre, M-A; Cardoso, J.N.; Macêdo, S.J.; Sci. Total Environ. 1999, 231,1.

14. Figueiredo, R.O.; Ovalle, A.R.C.; Water Air Soil Pollut. 1998, 105, 399.

15. Pedrosa, P.; Calasans, C.V.C.; Rezende, C.E.; Hydrobiology 1999, 411, 89.

16. Almeida, M.G.; MSci Dissertation, Universidade Estadual do Norte Fluminense, Campos dos Goytacazes, Brazil, 1998.

17. Gomes, A.O.; MSci Dissertation, Universidade Federal do Rio de Janeiro, Brazil, 1999.

18. Gomes, A.O.; Azevedo, D.A.; Abstracts of the 22th Annual Meeting of the Brazilian Chemical Society, Poços de Caldas, Brazil, 1999; Gomes, A.O.; Azevedo, D.A.; J. Braz. Chem. Soc. 2003, in press.

19. Harvey, H.R.; Bradshaw, S.A.; O'Hara, S.C.M.; Eglinton, G.; Corner, D.S.; Phytochemistry 1988, 27, 1723.

20. Nichols, P.D.; Volkman, J.K.; Hallegraff, G.M.; Blackburn, S.I.; Phytochemistry 1987, 26, 2537.

21. Cranwell, P.A.; Creighton, M.E.; Jawarshi, G.H.M.; Phytochemistry 1988, 27, 1053. 
22. Volkman, J.K.; Kearney, P.; Jeffrey, S.W.; Org. Geochem. 1990, $15,489$.

23. Klink, G.; Dreier, F.; Buchs, A.; Gülaçar, F.O.; Org. Geochem. 1992, 18, 757.

24. Rieley, G.; Collier, R.J.; Jones, D.M.; Eglinton, G.; Org. Geochem. 1991, 17, 901.

25. Jaffé, R.; Wolff, G.A.; Cabrera, A.C.; Carvajal-Chitty, H.; Geochim. Cosmochim. Acta 1995, 59, 4507.

26. Meyers, P.A.; Ishiwatari, R.; Org. Geochem. 1993, $20,867$.

27. Jaffé, R.; Elismé, T.; Cabrera, A.; Org. Geochem. 1996, 25, 9.

28. Servel, M-O.; Claire, C.; Derrien, A.; Coifford, L.; De RoeekHoltzhauer, A.; Phytochemistry 1994, 36, 691.

29. Cardoso, J.N.; Gaskel, S.J.; Quirk, M.M.; Eglinton, G.; Chem. Geol. 1983, 38, 107.

30. Simoneit, B.R.T.; Sheng, G.; Chen, X.; Fu, J.; Zhang, J.; Xu, Y.; Atmos. Environ. 1991, 25A, 2111.

31. Abas, M.R.; Simoneit, B.R.T.; Elias, V.; Cabral, J.A.; Cardoso, J.N.; Chemosphere 1995, 30, 995.

32. Grimalt, J.O.; Yreula, I.; Saiz-Jimenez, C.; Toka, J.; De Leeuw, J.W.; Albaigés, J.; Geochim. Cosmochim. Acta 1991, 55, 2555.

33. Simoneit, B.R.T.; Cox, R.E.; Standley, D.J.; Atmos. Environ. 1988, 22, 983.
34. Meyers, P.A.; Ishiwatari, R. In Organic Geochemistry. Principles and Applications; Engel, M.H.; Macko, S.A., eds., Plenum Press: New York, 1993, ch. 8, p. 185.

35. Tanzer, G.E.; Meyers, P.A.; Robbins, J.A.; Eadie, B.J.; Morehead, N.R.; Lansing, M.B.; Org. Geochem. 1999, 30, 133.

36. Jasper, J.P.; Gagosian, R.B.; Nature 1989, 342, 60.

37. Elias, V.O.; Simoneit, B.R.T.; Cardoso, J.N.; Extended Abstracts of the $7^{\text {th }}$ Latin American Congress on Organic Geochemistry, Foz do Iguaçu, Brazil, 2000.

38. Azevedo, D.A.; Santos, C.Y.M.; Aquino Neto, F.R.; Extended Abstracts of the $7^{\text {th }}$ Latin American Congress on Organic Geochemistry, Foz do Iguaçu, Brazil, 2000; Santos, C.Y.M.; Azevedo, D.A.; Aquino Neto, F.R.; Atmos. Environ. 2002, 36, 3009 .

39. Simoneit, B.R.T.; Mazurek, M.A.; Atmos. Environ. 1982, 16, 2139.

40. Simoneit, B.R.T.; Abas, M.R.; Cass, G.R.; Rogge, W.F.; Mazurek, M.A.; Standley, L.J.; Hildemann, L.M. In Remote Sensing, Modeling and Inventory Development, and Biomass Burning in Africa; Levine, J.S., ed., MIT Press: Cambridge, MA, 1996, vol. 1, ch. 48, p.509.

Received: August 30, 2001 Published on the web: February 12, 2003 